Article

\title{
Mass University and Social Inclusion: The Paradoxical Effect of Public Policies
}

\author{
Pierre Canisius Kamanzi ${ }^{1, *}$, Gaële Goastellec ${ }^{2}$ and Laurence Pelletier ${ }^{1}$ \\ ${ }^{1}$ Faculty of Education, University of Montreal, Canada; E-Mails: pierre.canisius.kamanzi@umontreal.ca (P.C.K.), \\ laurence.pelletier.5@umontreal.ca (L.P.) \\ 2 LACCUS/OSPS, Institute of Social Sciences, Faculty of Social and Political Sciences, University of Lausanne, Switzerland; \\ E-Mail: gaele.goastellec@unil.ch \\ * Corresponding author
}

Submitted: 7 February 2021 | Accepted: 19 April 2021 | Published: 21 July 2021

\begin{abstract}
The objective of this article is to revisit the role of public policies in the social production and reproduction of university access inequalities that have been made evident more than ever in the current intensified mass higher education context. Although the situation is complex and varies from one societal context to another, a systematic review of the existing literature highlights the undeniable responsibility of public policies in this reproduction through three main channels: guidance systems and educational pathways, institutions' stratification and hierarchization of fields of study and, finally, the financing of studies and tuition fees.
\end{abstract}

\section{Keywords}

educational policies; equity; higher education; inequality; public policies; social exclusion; university

Issue

This article is part of the issue "Inclusive Universities in a Globalized World" edited by Liudvika Leišyte (TU Dortmund, Germany), Rosemary Deem (Royal Holloway, UK) and Charikleia Tzanakou (Oxford Brookes University, UK).

(C) 2021 by the authors; licensee Cogitatio (Lisbon, Portugal). This article is licensed under a Creative Commons Attribution 4.0 International License (CC BY).

\section{Introduction}

Following the 1948 Universal Declaration of Human Rights, most states have recognized the right to education and their moral duty to implement it. In this context, the promotion of equality in higher education has also been considered as an essential instrument of justice and social cohesion (Brennan \& Naidoo, 2008; Goastellec, 2008). Beginning in the 1970s, mass higher education has gradually been established in various countries (Huberman, 1970), but it intensified between the 1980s and 1990s (Dubet, 1994; Trow, 2005). The acceleration of this massification is attributable to the affirmation of public and educational policies, and to the evolution of the connections between education and the economy, which have become increasingly close, especially in the tertiary sector (Guri-Rosenblit et al., 2007).
On the one hand, a higher education diploma has become a necessary condition for accessing quality employment over the decades (Bol, 2015; J. West, 2000). Jobs requiring a secondary education or less are becoming scarce while new jobs that are created, especially in the tertiary sector, require a postsecondary education (P. Brown et al., 2008; Powell \& Snellman, 2004). Also, salaries stagnate in jobs for secondary education holders: all else being equal (field of study and employment sector), higher education graduates hold higher-paying positions than high school graduates (Budria \& Telhado Pereira, 2005). Consequently, an increasing number of students are pursuing higher education: Between 1900 and 2000 , the number of students enrolled worldwide increased from 500,000 to $100,000,000$, a population 200 times larger (Schofer \& Meyer, 2005).

On the other hand, this massification results from policies linked to the democratization of education as 
a whole. Upstream, it is a continuation of generalized free and compulsory secondary education adopted by several countries after the Second World War (Meyer et al., 1992), which increased the number of secondary school graduates potentially eligible for postsecondary studies. Downstream, it is the result of the adoption of political measures aiming to expand access to postsecondary studies (Machin \& McNally, 2007; Schofer \& Meyer, 2005), such as increasing the number of institutions and resources, diversifying training fields, and making admission conditions more flexible. However, have university and, more broadly, higher education become equitable? In other words, has this massification contributed to reducing inequalities according to students' social and ethnic origin and other social affiliations, such as gender and place of residence (rural/urban)? Is the student body representative of the social diversity at the higher education system level as well as at the various institutions, disciplines and degrees levels?

Recent studies show that despite the increase in accessibility and heterogeneity of school populations, the expansion of higher education has brought along an increase in inequalities according to social origin (Shavit et al., 2007; Triventi, 2013). From a classic sociological perspective, this increase in inequalities can be interpreted as a combination of the effects of social reproduction (Bourdieu \& Passeron, 1990), student and family self-selective behaviors (Duru-Bellat, 2003), as well as student rational choices during their academic careers (Boudon, 1974). Although the explanatory contribution of these classic theories to social inequalities in educational pathways is undoubted, they do not provide a comprehensive understanding of the phenomenon. Indeed, supporters of these theories tend to place little importance on the influence of public policies.

Based on a meta-analysis of recent studies carried out in industrialized countries, this article aims to delve into the role of educational systems and public policies in the social production and reproduction of university access inequalities. This influence has been highlighted in several studies; however, there is still a need for research to address the complexity of the processes through which 'black box' educational systems participate concretely in the production, reproduction, or reduction of social inequalities, especially at the university level. While the effect of public policies on educational inequalities has a structural character due to the organization of school curricula and the degree of selectivity at various levels of education (Reichelt et al., 2019; Verdier, 2010), factors that perpetuate it are renewed over time and according to countries' fluctuating socioeconomic and political circumstances. Whatever the context, certain factors disappear, and others appear or are transformed according to the dynamics of social relations (social class, gender, and ethnicity) and public policies that are in place (Kromydas, 2017). It is therefore important that research regularly re-examines the association between public policies and social inequalities.
The objective of this article is to identify political factors specific to the contemporary period characterized both by the intensification of mass higher education through university, and by the perpetuation of social inequalities.

Our analysis of recent studies enabled us to highlight three main factors: (1) the guidance counseling systems at the secondary level, (2) the stratification of higher education, and (3) the financing of studies and tuition fees. The three factors are discussed in a general manner and on an international scale, showing that their effects should not be reduced to the national or local levels; rather, we view them as analytical avenues for any education system aiming to be equitable. We illustrate that public policies tend to have a rather paradoxical effect in relation to social inclusion in university education: Although governmental measures formally aim to democratize access to university and more broadly to education, our meta-analysis emphasizes that the opposite is observed in several cases. The analysis is divided into four sections. The first describes and contextualizes the social (re)production of educational inequalities in contemporary societies, while the subsequent sections respectively address three dimensions that the metaanalysis reveals as constitutive of these policies: the effects of guidance counseling systems and secondary school pathways, the stratified structure of higher education, and finally, the financing of studies and tuition fees. Before presenting the analysis, we describe in the next section the methodology mobilized to select our corpus of analyzed works.

\section{Methodology}

This article is based on a literature review of studies about the effect of public policies on the social (re)production of educational inequalities in higher education. These studies were identified using Google Scholar, Sociological Abstracts, Atrium, Érudit, ERIC and Cairn search engines and selected using the following descriptors and their French equivalents: educational inequality, education, higher education, university, postsecondary education, welfare state, educational policies, public policies. The two inclusion criteria consisted of the year of publication (from 2000) and language (English and French). However, a few studies (7) published before 2000 were selected because of their relevance, and because they concerned aspects that have not been addressed by recent studies (after 2000).

Subsequently, the selected texts were sorted. To be included, the articles had to research the effects of policies on educational pathways, and the relationship between these two variables had to be at the core of the analysis. At the end of the selection process, the corpus contained 101 articles and books. We then conducted a thematic analysis which yielded four main, but not exclusive, categories: (1) studies concerning the effects of public and educational policies on educational inequalities in general, (2) studies dealing with educational 
and professional guidance counseling inequalities in high schools, (3) studies emphasizing inequalities within education itself, and (4) studies focusing on obstacles linked to financial issues. These studies were carried out, for the most part, in European countries, in North America (USA and (anada), in a few Asian countries that are members of the OECD (Japan, South Korea) and in Australia. Some concern national contexts, while others are comparative studies between two or more countries. This relatively limited choice of countries finds support in the fact that those countries have effectively established mass university education. Although the goal of democratizing university access is affirmed in several other countries, they still face various obstacles. The comparative strategy adopted is mainly universalizing - aimed at establishing "that every instance of a phenomenon follows essentially the same rule" (Tilly, 1984, p. 82)-and, to some extent, "variation finding, i.e., seeking to establish a principle of variation in the character or intensity of a phenomenon by examining systematic differences between its instances" (Tilly, 1984).

\section{Contemporary Societies and the (Re)production of Inequalities in Education}

Research on the effects of public policies on educational inequalities and exclusion has particular relevance in the current context marked by the reconfiguration of the state's social role on a global scale (Alon, 2009; Ertul et al., 2012; Herr, 2003; Watts, 2008), notably in its disengagement in favor of greater empowerment of individuals (Brückner \& Mayer, 2005). In the name of meritocracy (performativity, efficiency and individual enterprising) promoted by neoliberal ideology (Apple, 2001), this dynamic of state disengagement materializes through the privatization (especially in Liberal welfare states) and commodification of public services such as education and legitimizes exclusion through competition and selection practices at the institutional level (Hill \& Kumar, 2009).

In a neoliberal context, educational development strategies are based on a system of accountability and on the promotion of students' and parents' freedom of choice:

In education, neoliberal strategies focus on highstakes accountability, increased assessment, and school choice. Under neoliberal reform, schools are mandated to increase the number of assessments they administer and are penalized or rewarded according to student performance. Schools are then classified by this performance, and this classification serves as a measure of school quality for parents when selecting schools. (Brathwaite, 2017, p. 430)

Although equity and social justice are promoted in the name of democracy, they actually give rise to inequalities. Hence, while prescribed pathways are currently less restrictive, not all individuals have equal opportu- nities and capacities to use the resources made available to them, nor to negotiate an educational pathway that allows them to access social and economic success (Ertul et al., 2012). From the perspective of Sen's (2000) capability approach, the existence of resources (goods and services) and of the formal right to access them is certainly a prerequisite to ensuring social justice, but it is not sufficient. It is also important that all concerned individuals are equipped with the capabilities to use them to achieve their goals. In this light, educational and vocational guidance counseling systems are not neutral (Dhume \& Dukic, 2012). They can contribute to reducing or increasing inequalities depending on the resources they make available to individuals, in conjunction with their ability to mobilize them (Wang, 2011).

Comparative international studies show that the persistence of social inequalities in education across generations is strongly rooted in the way educational institutions operate and is reinforced through public policies (A. West \& Nikolai, 2013). Societies differ from one another regarding the level of public influence and intervention within the management of educational institutions, and the financial aid available to individuals at risk of poverty. Depending on whether this intervention favors the freedom and autonomy of institutions or, on the contrary, supervision and support, the tendency is either towards segmentation and social disparities, or towards the harmonization of the system and social cohesion (Dubet et al., 2010). Such studies also bear witness to the fact that social inequalities in education vary according to societal contexts. Thus, they appear to be more moderate in societies where economic inequalities between individuals are low, or where diplomas have a moderate influence on the socioeconomic future of individuals (Goastellec, 2020). School policies operate via a set of social policies with which they interact. Namely, inequalities are reduced when measures to fight social injustice are adopted by governments and implemented by educational institutions at all levels (primary, secondary and university).

In sum, the link between social origin and higher education inequalities has a structural character based on the culture, history, and economic organization of societies (Altbach et al., 2009), as well as the organization of school trajectories, and the degree of selectivity at different levels of education (Dubet et al., 2010; Dupriez \& Dumay, 2006; Felouzis, 2009). The latter are themselves part of an ideological orientation (neoliberal, conservative, social-democratic) of public policies and the specific relationship between the labor market and each level of education (Pechar \& Andres, 2011; Willemse \& De Beer, 2013).

\section{Guidance Counseling and Secondary School Pathways}

Regardless of the education system, access to university is largely conditional on obtaining a secondary 
school diploma, even if alternative access avenues exist. However, depending on the organization of the education system, not all secondary school diplomas provide access to higher education and university especially. Education systems are comprised of secondary education pathways and programs, some of which are preparatory for higher education, while others are inclined to vocational training geared towards the labor market. The reproduction of social inequalities remains consistently pronounced across sectors since they are based on early selection and inter-compartmentalized (Dupriez \& Dumay, 2006; Hanushek \& Wößmann, 2006).

Several comparative international studies demonstrate the correlation between the extent of selectivity within sectors and the reproduction of inequalities. They highlight two trends (Dubet et al., 2010; Dupriez \& Dumay, 2006; Felouzis, 2009): differentiated and comprehensive educational systems. Differentiated systems are characterized by a separation of students and early orientation into hierarchical streams which generally operate on the basis of academic performance, often using selection tests. In Europe, differentiated systems are found in the Czech Republic, the Netherlands, and Germany (Dupriez \& Dumay, 2006). Differentiation is based on various arguments depending on the education system, but three of them seem to be the most often evoked, as underscored by Felouzis (2014). Firstly, student selection and guidance through hierarchical streams are based on the principle of meritocracy: More deserving and talented students must be offered training that matches their skills and meets their ambitions. In contrast, a less rigorous or ambitious pathway should be offered to weak or less gifted students; one that realistically allows them to succeed based on their abilities. The second argument is pedagogical and maintains that to increase the chances of success for all, students must be grouped into homogeneous classes; in doing so, it enables the adjustment of content and pedagogical approaches to their learning pace. Finally, the third argument asserts that this differentiation contributes to valuing weak or less gifted students: Assigning them to vocational training programs of short duration according to their interest allows avoiding or reducing the risk of failure and negative effects on self-esteem that may be encountered over the course of long-term schooling. Contrary to these arguments, selection mechanisms at the core of these groupings do not prevent social segregation or even exclusion, since the treatment (curricula and teaching resources) that students receive is often unequal and varies in subtle ways according to their social and ethnic origins (Bourdieu \& Passeron, 1990; Dhume \& Dukic, 2012; Meyers \& Gornick, 2003).

Conversely, comprehensive education systems are distinguishable by their common training structure over a long-term period (Dubet et al., 2010; Dupriez \& Dumay, 2006). Selection and orientation in hierarchical streams happen later in educational pathways or not at all. The number of enriched optional courses is also lim- ited. Ultimately, the goal of this common long-term training is to retain students for as long as possible so they may develop equal educational assets, while reducing the effects of family resources (or lack thereof) on school performance, access to graduate studies and professional integration. The principle of these systems is that the educational and professional orientation that follow depend more on student choices and their accumulated skills than the cultural, social, and economic capital of their parents. According to the same studies, most Anglo-Saxon and South-East Asian countries as well as Northern-European countries fall in this category.

The comparison of differentiated and comprehensive systems shows a strong positive correlation between the degree of educational differentiation and the extent of performance gaps between students from different social backgrounds. The gap between weak students (usually of modest origins) and strong students (usually from wealthy families) increases as the system becomes more differentiated and vice versa. In differentiated systems, weak students do not have enough time to improve their performance to close the gap between themselves and stronger students because the two groups are separated from the first years to follow different and hierarchized programs (Dupriez \& Dumay, 2006). These systems are more likely to maintain a strong relationship between social origin and educational inequalities through earlier and successive guidance at the different levels of primary and secondary education. As Le Donné's (2014) study shows, this is the case in several countries of Continental Europe where secondary education is divided into two or three levels of educational and vocational guidance and students are subject to successive selection processes. Early orientation, which in some countries (e.g., Germany, Austria, the Czech Republic, and Hungary) begins at age 10 in primary school, contributes to perpetuating social homogenization. The case of Germany offers a good illustration as evidenced by Neugebauer et al. (2013). After primary education, students are selected and sorted based on their academic performance, then oriented in three hierarchical streams: The first, the Hauptschule, is meant for those with poor academic results; it lasts five years, offers vocational training, and its diploma does not provide access to higher education. The second (Reaschule) includes intermediate level students; it lasts six years and prepares students for white-collar jobs, middle management positions in business or skilled trade occupations. Graduates of this stream are not university-eligible but may be admitted to other types of higher education institutions, provided they successfully complete an additional ad hoc training. Finally, the Gymnasium is reserved for strong students and prepares them to university studies. Although parental choice is considered in some states, its influence on admission to the three streams is very limited. Educational guidance is strongly correlated with parents' income and level of education. Only one in three students (32\%) whose parents have a low level of 
education is admitted to the Gymnasium, while among those whose parents have a higher education degree, the proportion is three in four (76\%). Likewise, only $26 \%$ of students whose parents have a lower income access the Gymnasium, while this rate reaches $73 \%$ in the case of high-income families.

In comprehensive systems (i.e., the Nordic countries, Poland, Spain, and Iceland), the gap between weak and strong students is also present and correlated with parents' socioeconomic status. However, it tends to be smaller compared to differentiated systems (Le Donné, 2014). Extending the duration of the common core program gives weak students the chance to improve their performance and reduces the gap between them and strong pupils who, as stated above, generally come from socially advantaged backgrounds. Therefore, leveling the educational options would help reduce social inequalities in educational and vocational guidance.

Although the existence of a common program is favorable to equal chances of success and academic performance, it is not sufficient. This equalization is, first of all, based on a culture of social justice that characterizes a system, which is also embedded in social organization (Dubet et al., 2010). Such a culture rests on social cohesion and the implementation of concrete measures to combat all forms of exclusion in various spheres of social life (education, labor market, housing, health, leisure, etc.). In other words, not all integrated systems are necessarily egalitarian. The scope of school integration varies according to public policies and social relations between families often involving competition (Verdier, 2010), but also mainly according to the regulation of institutional practices (lannelli, 2013). Even in the presence of a common program, the reconfiguration of the link between social and educational inequalities can be maintained through socially accepted practices of segregation in institutions: for example, parents' right to choose their children's school (Van Zanten, 2009), the link between the quality of institutions and the social organization of neighborhoods, which favors socially homogeneous student groupings in the same schools (François \& Poupeau, 2004), learning differentiation and the proliferation of optional courses (Felouzis, 2009; Kamanzi, 2019; Kamanzi et al., 2020), the autonomy of institutions to adapt or reorganize programs, as well as competition between institutions (Draelants, 2013; Kamanzi, 2019).

The case of the USA is eloquent in this regard, as evidenced by Brathwaite (2017). Parents' right to choose schools allows families to enroll their children in institutions located outside the area of residence. This right is more beneficial to families with high economic, cultural, and social capital, able to access information and mobilize the necessary financial resources. More often driven by the rejection of social diversity, these families target schools mainly attended by children of the same social classes. This phenomenon is especially frequent in neighborhoods characterized by socioeconomic inequal- ities and ethnic heterogeneity. Its consequences are the social homogenization of schools and the marginalization of students from poor families in the same schools. Students from cultural minorities and socioeconomically disadvantaged backgrounds find themselves concentrated in institutions marked by low performances, a bad climate, lower quality resources (human and material), an anti-school culture and high dropout rates. This situation is very common among students from Black and Spanish-speaking communities of Latin American origin; as a result, few of these students persevere through higher education, especially university.

In sum, the link between social origin and educational inequalities has a structural character anchored in the organization of school curricula and is correlated with the degree of selectivity at the different levels of education (Hillmert \& Jacob, 2002; Verdier, 2010). Internal to each system, mechanisms that allow students to be divided into educational pathways predispose them to educational inequalities at upper levels (Draelants, 2013). The differentiation between these pathways establishes institutional enclosures between spaces in the educational system that are protected from the effects of massification and reserved for the elite. In contrast, there are those that can be viewed as 'parking lots' that lead to careers such as manual trades with no lane towards postsecondary studies. Of course, in a context of equal access in schools, admission to general education courses leading to higher education is based on academic results, as well as on student and parent choices, but it must be emphasized that public policies are far from neutral. They operate directly (Checchi et al., 2014), indirectly, and invisibly through institutional selection practices (Gibbs, 2002; Reay, 2004), such as tracking, separating, and grouping students by abilities in classes offering unequal quality of education (Dupriez, 2010). As a result, social inequalities in university should be considered as the result of cumulative exclusions (Tsui, 2003).

The following section demonstrates that while massification increased access opportunities for all social groups, the negative social effects of differentiation on educational pathways are accentuated by the stratification and segmentation of higher education.

\section{The Stratification of Higher Education}

Higher education massification policies have contributed to reducing social inequalities in terms of university access, at least initially (e.g., Cantwell et al., 2018; Goastellec, 2020; Liu et al., 2016). However, massification does not guarantee a decrease in postsecondary access inequalities, and can also cause a displacement and an accentuation of inequalities within higher education when coupled with policies of supply stratification.

Indeed, mass higher education has not only been characterized by an increase in student numbers and heterogeneity, but also by a proliferation of institutions and 
the diversification of the training offer. Driven by the theory of human capital (Becker, 1964/1993), industrialized societies and their governments have considered training a critical mass of highly skilled laborers as essential to meet the needs of a growing knowledge economy (Olssen \& Peters, 2005). Over the past three decades, economic growth has enabled public authorities to invest more resources in higher education and de facto, to legitimize the right of governments to exercise direct or indirect control over institutions, whether in terms of management or educational programs (Slaughter \& Leslie, 1997). In turn, the expansion of higher education has helped creating mechanisms for sustainable economic development supported by research, knowledge generation, and innovation (Peters, 2013; Kruss et al., 2015). Finally, we are witnessing the interweaving of developments in the economic and educational markets, which is accentuated under the effect of globalization and the expansion of neoliberalism (Boguslavskii \& Neborskii, 2016; Lynch, 2006; Olssen \& Peters, 2005).

Along with accessibility measures and higher education expansion, public authorities have invested significant resources in the differentiation and diversification of training structures and have offered to increase the capacity of education systems to respond to increasingly diversified social and economic demands (Marginson, 2015, 2016b; Triventi, 2013). In terms of structure, we observe to varying degrees cohabitation, often accompanied by competition between private and public institutions. Fueled by globalization and economic competition between countries, this dynamic contributed to transforming higher education systems into a market (R. Brown, 2008; Callender \& Dougherty, 2018; Chapman, 2008; Gibbs, 2002). On the one hand, students and parents struggle to access the most prestigious institutions, meaning reputed to provide superior training and increase chances of accessing employment of high socioeconomic status. On the other hand, to maintain or increase their prestige, institutions are encouraged to play the same game of competition among themselves to acquire more financial resources-whether private or public-but above all, better quality students either locally or internationally, who constitute the most important resource in education (Clark, 2009). In several national contexts, this competitive game has been transferred within institutions and has led to the hierarchization of fields and courses of study (Marginson, 2016b).

In a comparative analysis of 11 European countries, Triventi (2013) shows that the reproduction of social inequalities in higher education is linked with institutional stratification in two ways. Firstly, students from culturally advantaged backgrounds have greater chances of graduating from a prestigious institution, with a degree of a higher status and with more advantageous occupational outcomes. Secondly, the author finds an association between parents' education and the prestige of the students' field of study. Also highlighting this link between stratification and educational inequalities,
Marginson (2016b) notes that massified higher education systems in socioeconomically unequal societies such as the USA have a tendency to be more stratified; as a result, the effects of social background in educational attainment are strengthened. In the United Kingdom, R. Brown (2018) stresses that the competition between individuals and institutions, amplified by the marketization of higher education, generates a stratification of the institutions, which is associated with the socioeconomic composition of the students they enroll. All in all, the greater the institutional stratification, the greater the access inequalities based on social origin, as underscored by the comparative studies of Davies and Zarifa (2012) in the USA and Canada, Liu et al. (2016) in OECD Countries.

In the name of meritocracy and educational system efficiency, the institutional stratification and the hierarchy of fields of study have established new institutional barriers and legitimized social exclusion in spaces that are protected from higher education and the job market. As summarized by Marginson (in Cantwell et al., 2018, p. 167): "There is a common failure to democratize the elite institutions during the massification process." The work of these authors on High Participation Systems (HPS) also underscores the following dynamic: while massification is not necessarily associated with horizontal diversification-but rather with a decline in educational diversity-vertical stratification is important and contributes to inequalities. They note that "with the expansion of participation, plus greater institutional stratification and associated social competition in education, there is a secular tendency to social inequality" (Cantwell et al., 2018, p. 449). The authors thus highlight a strong tendency towards separating a small elitist university sector from a large university sector absorbing the demand for access. According to these authors, this stratification stems from social dynamics that are distinct from the process of massification on its own. Here we find the hypothesis that competition between individuals and between institutions reinforces stratification all the more as systems are massified, except when proactive policies to limit these effects are implemented (Liu et al., 2016).

With massification, "the positional structure of the higher education system increasingly resembles that of society. The High Participation System is increasingly implicated in the reproduction of existing patterns of social equality/inequality" (Cantwell et al., 2018, p. 448). This is also reflected in international comparative studies on welfare regimes and higher education, which report fewer inequalities in less stratified social democratic systems of Northern Europe (Pechar \& Andres, 2011; Willemse \& De Beer, 2013). According to Pechar and Andres (2011), in Nordic countries, higher education systems promote expansion while ensuring social protection for individuals who do not have the ability or the will to pursue a university education. Aside from generous loans and grants, high public expenses, and low private financing, public policies include a pronounced 
institutional standardization, which contributes to reducing overall inequalities in higher education (Willemse \& De Beer, 2013). However, a recent review of literature argues that since the 1990s, the social democratic model characterized by high standardization has been challenged by an increased institutional stratification (Isopahkala-Bouret et al., 2018).

All things considered, studies focusing on the stratification of higher education underline the importance of political choices made to support and accompany massification and, consequently, the variety of national configurations in which more or less significant inequalities of access are embedded. It is in the structure and organization of university systems that the social contract specific to each society is expressed, and not in the process of massification itself. The link between the reproduction of social inequalities and the internal organization of higher education seems thus deeply rooted in policies that "take place within frameworks of historical institutionalization that differ qualitatively between countries" (Esping-Andersen, 1990, p. 80).

\section{Financing of Studies and Tuition Fees}

As we previously highlighted, the competition that characterizes higher education has been associated with economic issues: In an era of national deficits, some governments tended to reduce the amount of basic funding to universities (Bahrs \& Siedler, 2019; Slaughter \& Leslie, 1997). In a dynamic of competition for financial resources, universities aimed to diversify their sources of income (Goastellec, 2012). This diversification of income implied, among other things, a greater financial contribution from students, perceived as consumers of a service (Slaughter \& Rhoades, 2004). In this light, the trend of rising tuition fees in industrialized countries (Goastellec, 2012; Marginson, 2016a) has been linked to the social reproduction of inequalities of access to university education.

Among public policies affecting education, financial policies are considered as an important tool to compensate for inequalities. They are the subject of recurrent and contradictory debates, especially with regard to tuition fees. For some analysts like Castro and Poitevin (2018), it is the students' (and parents') responsibility to assume part of the training costs since they are the main beneficiaries of the human capital thus produced. Without denying the social return generated by university education, the authors emphasize that it brings a higher private return than primary and secondary education, since university studies are only accessible to a limited section of society. Recognizing, however, that high tuition fees can be a barrier for young people from low-income families, the authors advocate for a public policy of increased financial assistance and the least restrictive repayment terms as possible.

In contrast, opposers of tuition fees and defenders of free higher education base their arguments on the prin- ciple that these represent a welfare good (Martin, 2016). Higher education is a good that is essential to human dignity (Calame \& Ziaka, 2015) and, consequently, a social right for every citizen who requests it. As Martin (2016, pp. 9-10) highlights:

Higher education should be available to all because it is necessary for living a good life. Here higher education is understood to be a welfare good in the same class as health care and basic schooling. It is something to which citizens have a social right.

Following this perspective, higher education should be conceived as 'morally special,' as it contributes to human development (autonomy, social and individual well-being, health, freedom, etc.) and to the production of other goods for society according to its priorities (Martin, 2016). Therefore, the author argues that tuition fees and the debt they impose distract citizens from their moral and democratic duty to society, since the only important obligation after graduation is to repay the debts incurred. Conversely, when all the costs of studies are covered by public authorities, graduates integrate the moral duty to fully mobilize their acquired knowledge to contribute to the development of their societies.

On another level, financial policies regarding both fees and student financial supports inform the conception of students as autonomous individuals or dependent on their families, and as socio-philosophically associated with a state model. In this regard, Charles (2015) shows how in socio-democratic states students are considered as autonomous individuals through funding policies that center on social equality and freedom of choice. In the 'Swedish metro' of higher education, student pathways are open, and the consolidation of work and studies is encouraged to help reduce the influence of a diploma on economic outcomes. The financing of studies does not consider parents' resources nor the linearity of the educational path. In this light, the financing of studies appears to be a universal right. This is not the case in conservative regimes: Families' socioeconomic resources influence those that are made available by the welfare state. As for liberal regimes, they index funding to family characteristics and individual academic success. These educational financing policies are derived from the social philosophy specific to each country.

Beyond these philosophical principles that guide public authorities' decisions, what does empirical research tell us about the effect of tuition fees on social equity? Studies in several developed countries show that a rise in tuition fees decreases access to university for certain groups of young people. In Germany, Bahrs and Siedler (2019) studied the impact of tuition fees on high school students' intention to obtain a university degree. Their analysis concludes that the introduction of $€ 1,000$ annual tuition fees in Germany had a negative impact on 17-year-olds' intention to pursue a higher education training: Proportions declined overall by $10 \%$, with 
a particularly steep decrease in low-income-household students (33\%). In Canada, Doray et al. (2015) observe a double effect of tuition fees on certain social groups' access to university: $A$ rise of $\$ 1,000$ in annual fees decreases first-generation students' access by $19 \%$ and increases access by $10 \%$ for students whose parents hold university degrees. In the USA, Allen and Wolniak (2019) conducted multivariate analyses to verify the effects of an increase in tuition fees at public colleges and universities on institutions' racial and ethnic diversity. Their results suggest that tuition increases are negatively linked to the racial and ethnic diversity of institutions' student population. Also, studies by Coelli (2009) in Canada, Callender (2008) and Galindo-Rueda et al. (2004) in England show that a rise in university tuition fees coincides with declining enrollment for students from low-income families. In conclusion, high tuition fees thus seem to constitute an obstacle to access to higher education for young people from low-income families while the same trend does not apply to their peers from middle-and higher-income families, as evidenced by the comparative study of Liu et al. (2016) in OECD countries.

\section{Conclusion}

The objective of this article was to revisit the role of public policies in the social production and reproduction of university access inequalities in contemporary massified higher education systems. Our comparative analysis of contemporary studies highlights the universal and undeniable responsibility of public policies in this reproduction. This is mainly the result of exclusion mechanisms based on successive selection instituted by public authorities. At the secondary level, the influence of public policies acts through educational and vocational guidance systems in academic streams and curricula leading to university and, more broadly, to higher education. Defined by political powers, these systems are often vectors of segregation. The social and ethnic exclusion as the result of selection is to the advantage of students from families endowed with cultural and economic resources. After secondary school, students admitted to university undergo a second selection process and those of disadvantaged social and ethnic origins are subjected to a second exclusion process; few of them are admitted to prestigious universities and fields of study that are socially valued and rewarding in the labor market (Di Pietro \& Cutillo, 2006; McGuinness, 2003). As previously mentioned, different countries allow these selections to multiply to promote competition and institutional stratification, as well as the prioritization of streaming and university training courses (Bloch \& Mitterle, 2017). Finally, another source of exclusion concerns the financing of studies. Governments can provide universal funding for studies and may or may not allow institutions to charge students tuition fees to increase their financial resources. These fees can accentuate social exclusion when arrangements are not in place to ensure adequate financial support for students from low-income families. In sum, mass university is not synonymous with social justice. On the contrary, it conceals social inequalities which are reproduced through different forms of social segregation and exclusion. Paradoxically, these are often generated by institutional practices, governed by public policies, in the name of social justice.

The way these three main dimensions combine varies depending on the countries and along the lines of the welfare state types and their intrinsic equality principles. Three main types of combinations are particularly salient in countries with massified higher education systems: early official tracking at secondary level, moderately stratified higher education and low to moderate fees and financial support (conservative model); internal tracking, highly stratified higher education, high fees and financial support (liberal model); little tracking at secondary education, little higher education stratification, low fees and highly important support (socialdemocratic model). These combinations lead to various levels of inequality (Goastellec, 2020), the latter thus directly resulting from policy choices.

Still, as mentioned in the introduction, the influence of factors associated with public policies analyzed in this article does not act alone. It operates in tandem with social factors, notably the cultural, social, and economic capital of parents (Galindo-Rueda et al., 2004; Reay, 2004). In other words, the production of social inequalities is shared between responsibilities assumed by families and public authorities, as recalled by Van Zanten (2005), as well as Motel-Klingebiel et al. (2005). However, the way in which this partitioning takes place fluctuates over time and space depending on political choices (Checchi et al., 2014). As Whelan et al. (2011) point out, the degree of intergenerational mobility, or the persistence of social reproduction, is ultimately strongly anchored in the history of each society, the evolution of public policies, and the inner workings of social institutions. The influence of social and ethnic origin and characteristics on the reproduction of educational inequalities is closely linked to public policies that can mitigate or accentuate it through the regulation of institutional practices (Checchi et al., 2014; Reay, 2004). In all cases, contemporary research supports the claim that the persistence of social inequalities in the context of mass university is highly policy dependent. Policy matters, as much to sustain, reproduce, or limit inequalities.

If in contemporary societies, higher education is recognized as a common good and an instrument for improving individual and social well-being and social cohesion (Calame \& Ziaka, 2015; McMahon, 2018), it is all the more time that university access and its various fields and levels of training become equitable.

\section{Acknowledgments}

The authors would like to thank the reviewers for their very pertinent comments on this article. 


\section{Conflict of Interests}

The authors declare no conflict of interests.

\section{References}

Allen, D., \& Wolniak, G. C. (2019). Exploring the effects of tuition increases on racial/ethnic diversity at public colleges and universities. Research in Higher Education, 60(1), 18-43. https://doi.org/10.1007/s11162018-9502-6

Altbach, P. G., Reisberg, L., \& Rumbley, L. E. (2009). Trends in global higher education: Tracking an academic revolution. A report prepared for the UNESCO 2009 world conference on higher education. UNESCO.

Alon, S. (2009). The evolution of class inequality in higher education: Competition, exclusion, and adaptation. American Sociological Review, 74, 731-755.

Apple, M. W. (2001). Comparing neo-liberal projects and inequality in education. Comparative Education, 37(4), 409-423. https://doi.org/10.1080/ 03050060120091229

Bahrs, M., \& Siedler, T. (2019). University tuition fees and high school students' educational intentions. Fiscal Studies, 40(2), 117-147. https://doi.org/10.1111/ 1475-5890.12185

Becker, G. S. (1993). Human capital. A theoretical and empirical analysis. Columbia University Press. (Original work published 1964)

Bloch, R., \& Mitterle, A. (2017). On stratification in changing higher education: The "analysis of status" revisited. Higher Education, 73, 929-946. https://doi.org/ 10.1007/s10734-017-0113-5

Boguslavskii, M. V., \& Neborskii, Y. V. (2016). Development of the university education in the context of globalization. SHS Web of Conferences, 29. https:// doi.org/10.1051/shsconf/20162901011

Bol, D. T. (2015). Has education become more positional? Educational expansion and labour market outcomes, 1985-2007. Acta Sociologica, 58(2), 105-120.

Boudon, R. (1974). Education, opportunity, and social inequality: Changing prospects in Western societies. Willey.

Bourdieu, P., \& Passeron, J.-C. (1990). Reproduction in education, society and culture. Sage Publications.

Brathwaite, J. (2017). Neoliberal educational reform and perpetuation of inequality. Critical Sociology, 43(3), 429-448.

Brennan, J., \& Naidoo, R. (2008). The future of higher education and the future of higher education research. Higher Education, 56(3), 287-302.

Brown, P., Lauder, H., \& Ashton, D. (2008). Education, globalisation and the future of the knowledge economy. European Educational Research Journal, 7(2), 131-156.

Brown, R. (2008). Higher education and the market. Perspectives: Policy and Practice in Higher Educa- tion, 12, 78-83. https://doi.org/10.1080/13603100 802181125

Brown, R. (2018). Higher education and inequality. Perspectives: Policy and Practice in Higher Education, 22(2), 37-43. https://doi.org/10.1080/13603108. 2017.1375442

Brückner, H., \& Mayer, K. U. (2005). De-standardization of the life course: What it might mean? And if it means anything, whether it actually took place? Advances in Life Course Research, 9, 27-53. https:// doi.org/10.1016/S1040-2608(04)09002-1

Budria, S., \& Telhado Pereira, P. (2005). Does education reduce wage inequality? Quantile regression evidence from 16 countries. Labour Economics, 11(3), 355-371.

Calame, P., \& Ziaka, Y. (2015). Les biens communs et l'éthique de la responsabilité [Common goods and the ethics of responsibility]. Éthique publique, 17(2). https://doi.org/10.4000/ethiquepublique.2306

Callender, C. (2008). Access to higher education in Britain: The impact of tuition fees and financial assistance. In P. N. Teixeira, D. B. Johnstone, M. J. Rosa, \& H. Vossensteyn (Eds.), Cost-sharing and accessibility in higher education: A fairer deal? (pp. 105-132). Springer.

Callender, C., \& Dougherty, K. J. (2018). Student choice in higher education-Reducing or reproducing social inequalities? Social Sciences, 7(10). https://doi.org/ 10.3390/socsci7100189

Cantwell, C., Marginson, S., \& Smolentseva, A. (2018). High participation systems of higher education. Oxford University Press.

Castro, R., \& Poitevin, M. (2018). Niveau et modulation des frais de scolarité: Une analyse économique [Level and modulation of tuition fees: An economic analysis]. In M. Joanis \& C. Montmarquette (Eds.), Le Québec économique 7: Éducation et capital humain [The economic Quebec 7: Education and human capital] (pp. 179-203). Presses de l'Université Laval \& CIRANO.

Chapman, B. (2008). Income related student loans: Concepts, international reforms and administrative challenges. In P. N. Teixeira, D. B. Johnstone, M. J. Rosa, \& H. Vossensteyn (Eds.), Cost-sharing and accessibility in higher education: A fairer deal? (pp. 79-103). Springer.

Charles, N. (2015). Enseignement supérieur et justice sociale. Sociologie des expériences étudiantes en Europe [Higher education and social justice. Sociology of student experiences in Europe]. Observatoire National de la vie étudiante.

Checchi, D., van de Werfhorst, H., Braga, M., \& Meschi, E. (2014). The policy response: Education. In W. Salverda, B. Nolan, D. Checchi, I. Marx, A. McKnight, I. Tóth, \& H. van de Werfhorst (Eds.), Changing inequalities and societal impacts in rich countries: Analytical and comparative perspectives (pp. 294-327). Oxford University Press.

Clark, D. (2009). The performance and competitive 
effects of school autonomy. Journal of Political Economy, 117(4), 745-783.

Coelli, M. (2009). Tuition fees and equality of university enrollment. Canadian Journal of Economics, 42(3), 1072-1099. https://doi.org/10.1111/j.15405982.2009.01539.x

Davies, S., \& Zarifa, D. (2012). The stratification of universities: Structural inequality in Canada and the United States. Research in Social Stratification and Mobility, 30(2), 143-158.

Dhume, F., \& Dukic, S. (2012). Orientation scolaire et inégalités de traitement selon "l'origine": Une synthèse critique des connaissances [Educational guidance and treatment inequalities according to "origin": A critical synthesis of knowledge]. Diversité: Ville école intégration, 167, 165-175. https://halshs. archives-ouvertes.fr/halshs-01421933/document

Di Pietro, G., \& Cutillo, A. (2006). University quality and labour market outcomes in Italy. Labour, 20, 37-62.

Doray, P., Laplante, B., \& Bastien, N. (2015). What impact does the raising of tuition fees have on access to university? The example of Quebec. Regards croisés sur l'économie, 16(1), 162-175. https://doi.org/ $10.3917 /$ rce.016.0162

Draelants, H. (2013). L'effet établissement sur la construction des aspirations d'études supérieures [The role of secondary school for students' pursuit of higher education]. L'orientation scolaire et professionnelle, 42(1), 1-26. https://doi.org/10.4000/osp. 4028

Dubet, F. (1994). Dimensions et figures de l'expérience étudiante dans l'université de masse [Dimensions and figures of the student experience in the mass university]. Revue française de sociologie, 35, 511-532.

Dubet, F., Duru-Bellat, M., \& Vérétout, A. (2010). Les sociétés et leur école: Emprise du diplôme et cohésion sociale [Societies and their schools: Higher education degree influence and social cohesion]. Seuil.

Dupriez, V. (2010). Methods of grouping learners at schools. Fundamentals of educational planning 93. IIEP-UNESCO.

Dupriez, V., \& Dumay, X. (2006). Inequalities in school systems: Effect of school structure or of society structure? Comparative Education, 42(2), 243-260. https://doi.org/10.1080/03050060600628074

Duru-Bellat, M. (2003). Les inégalités sociales à l'école et les politiques éducatives [Social inequalities at school and educational policies]. UNESCO.

Ertul, S., Melchior, J.-P., \& Warin, P. (2012). Les parcours sociaux à l'épreuve des politiques publiques [Social careers and public policies]. Presses Universitaires de Rennes.

Esping-Andersen, G. (1990). The three worlds of welfare capitalism. Princeton University Press.

Felouzis, G. (2009). Systèmes éducatifs et inégalités scolaires: Une perspective internationale [Education systems and school inequalities: An international per- spective]. SociologieS. http://sociologies.revues.org/ 2977

Felouzis, G. (2014). Les inégalités scolaires [Educational inequalities]. Presses Universitaires de France.

François, J.-C., \& Poupeau, F. (2004). L'évitement scolaire et les classes moyennes à Paris [School avoidance and the middle classes in Paris]. Education et sociétés, 14(2), 51-66.

Galindo-Rueda, F., Marcenaro-Gutierrez, O., \& Vignoles, A. (2004). The widening socio-economic gap in UK higher education. National Institute Economic Review, 190(1), 75-88. https://doi.org/10.1177/ 002795010419000108

Gibbs, P. (2002). From the invisible hand to the invisible handshake: Marketing higher education. Research in Post-Compulsory Education, 7(3), 325-338. https:// doi.org/10.1080/13596740200200134

Goastellec, G. (2008). Globalization and implementation of an equity norm in higher education. Peabody Journal of Education, 83(1), 71-85.

Goastellec, G. (2012). Towards an economy of access: Changes in funding equality of opportunities, changes in individual and institutional freedom? In C. Koscielniak \& J. Makowsky (Eds.), Freedom, equality, university (pp. 173-194). Warsaw: Civic Institute.

Goastellec, G. (2020). Production de l'université, Production de la société. Sociologie de l'accès à l'université depuis le Moyen Âge [Production of the university, production of the society. Sociology of access to university since the Middle Ages]. Institut d'Études Politiques.

Guri-Rosenblit, S., Šebková, H., \& Teichler, U. (2007). Massification and diversity of higher education systems: Interplay of complex dimensions. UNESCO.

Hanushek, E. A., \& Wößmann, L. (2006). Does educational tracking affect performance and inequality? Differences in-differences evidence across countries. The Economic Journal, 116, C63-C76.

Herr, E. L. (2003). The future of career counseling as an instrument of public policy. Career Development Quarterly, 52(1), 8-17.

Hill, D., \& Kumar, R. (2009). Global neoliberalism and education and its consequences. Taylor \& Francis.

Hillmert, S., \& Jacob, M. (2002). Social inequality in higher education. Is vocational training a pathway leading to or away from university? European Sociological Review, 19(3), 319-334.

Huberman, M. (1970). International education year 1970. Reflections on democratization of secondary and higher education. UNESCO.

lannelli, C. (2013). The role of the school curriculum in social mobility. British Journal of Sociology of Education, 34(5/6), 907-928. https://doi.org/10.1080/ 01425692.2013 .816031

Isopahkala-Bouret, U., Börjesson, M., Beach, D., Haltia, N., Jónasson, J. T., Jauhiainen, A., \& Vabø, A. (2018). Access and stratification in Nordic higher education. A review of cross-cutting research themes and issues. 
Education Inquiry, 9(1), 142-154. https://doi.org/ 10.1080/20004508.2018.1429769

Kamanzi, P. C. (2019). School market in Quebec and the reproduction of social inequalities in higher education. Social Inclusion, 7(1), 18-27.

Kamanzi, P. C., Maroy, C., \& Magnan, M.-O. (2020). L'accès aux études supérieures au Québec: L'incidence du marché scolaire [Access to higher education in Quebec: The impact of the education market]. Revue française de pédagogie, 208(3), 49-64. https://doi.org/10.4000/rfp.9481

Kromydas, T. (2017). Rethinking higher education and its relationship with social inequalities: Past knowledge, present state and future potential. Palgrave Commun, 3(1). https://doi.org/10.1057/s41599-0170001-8

Kruss, G., McGrath, S., Petersen, I.-H., \& Gastrow, M. (2015). Higher education and economic development: The importance of building technological capabilities. International Journal of Educational Development, 43, 22-31.

Le Donné, N. (2014). European variations in socioeconomic inequalities in students cognitive achievement: The role of educational policies. European Sociological Review, 30(3), 329-343. https://doi.org/ 10.1093/esr/jcu040

Liu, Y., Green, A., \& Pensiero, N. (2016). Expansion of higher education and inequality of opportunities: A crossnational analysis. Journal of Higher Education Policy and Management, 38(3), 242-263.

Lynch, K. (2006). Neo-liberalism and marketisation: The implications for higher education. European Educational Research Journal, 5(1), 1-17.

Machin, S., \& McNally, S. (2007). Tertiary education systems and labour markets. OCDE.

Marginson, S. (2015). Global stratification in higher education. In S. Slaughter \& B. J. Taylor (Eds.), Higher education, stratification and workforce development: Competitive advantage in Europe, the US and Canada (pp. 13-34). Springer.

Marginson, S. (2016a). Higher education and the common good. Melbourne University Press.

Marginson, S. (2016b). The worldwide trend to high participation higher education: Dynamics of social stratification in inclusive systems. Higher Education, 72, 413-434. https://doi.org/10.1007/s10734-0160016-x

Martin, C. (2016). Should students have to borrow? Autonomy, wellbeing and student debt. Journal of Philosophy of Education, 50(3), 351-370.

McGuinness, S. (2003). University quality and labour market outcomes. Applied Economics, 35(18), 1943-1955. https://doi.org/10.1080/0003684032 000158442

McMahon, W. W. (2018). The total return to higher education: Is there underinvestment for economic growth and development? The Quarterly Review of Economics and Finance, 70, 90-111.
Meyer, J., Ramirez, F., \& Soysal, Y. (1992). World expansion of mass education, 1870-1980. Sociology of Education, 65(2), 128-149. https://doi.org/10.2307/ 2112679

Meyers, M. K., \& Gornick, J. C. (2003). Public or private responsibility? Early childhood education and care, inequality, and the welfare state. Journal of Comparative Family Studies, 34(3), 379-411.

Motel-Klingebiel, A., Tesch-Roemer, C., \& Von Kondratowitz, H.-J. (2005). Welfare states do not crowd out the family: Evidence for mixed responsibility from comparative analyses. Ageing \& Society, 25, 863-882.

Neugebauer, M., Reimer, D., Schindler, S., \& Stocké, V. (2013). Inequality in transitions to secondary school and tertiary education in Germany. In M. Jackson (Ed.), Determined to succeed? Performance versus choice in educational attainment (pp. 56-88). Stanford University Press.

Olssen, M., \& Peters, M. A. (2005). Neoliberalism, higher education and the knowledge economy: From the free market to knowledge capitalism. Journal of Education Policy, 20(3), 313-345.

Pechar, H., \& Andres, L. (2011). Higher education policies and welfare regimes: International comparative perspectives. Higher Education Policy, 24(1), 25-52.

Peters, M. A. (2013). Education, sciences and knowledge capitalism. Creativity and promise of openness. Peter Lang.

Powell, W. W., \& Snellman, K. (2004). The knowledge economy. Annual Review Sociology, 30, 199-220.

Reay, D. (2004). It's all becoming a habitus': Beyond the habitual use of habitus in educational research. British Journal of Sociology of Education, 25(4), 431-444.

Reichelt, M., Collischon, M., \& Eberl, A. (2019). School tracking and its role in social reproduction: Reinforcing educational inheritance and the direct effects of social origin. The British Journal of Sociology, 70(4), $1-26$.

Schofer, E., \& Meyer, J. W. (2005). The world expansion of higher education in the twentieth century. American Sociological Review, 70, 898-920.

Sen, A. (2000). Repenser l'inégalité [Rethinking inequality]. Seuil.

Shavit, Y., Arum, R., \& Gamoran, A. (2007). Stratification in higher education: A comparative study. Stanford University Press.

Slaughter, S., \& Leslie, L. L. (1997). Academic capitalism: Politics, policies, and the entrepreneurial university. The Johns Hopkins University Press.

Slaughter, S., \& Rhoades, G. (2004). Academic capitalism and the new economy: Markets, state, and higher education. Johns Hopkins University Press.

Tilly, C. (1984). Big structures, large processes, huge comparisons. Russel Sage Foundation.

Triventi, M. (2013). Stratification in higher education and its relationship with social inequality: A comparative study of 11 European countries. European Sociologi- 
cal Review, 29(3), 489-502. https://doi.org/10.1093/ esr/jcr092

Trow, M. (2005). Reflections on the transition from elite to mass to universal access: Forms and phases of higher education in modern societies since WWII. In J. F. Forest \& P. Altbach (Eds.), International handbook of higher education (pp. 243-280). Springer.

Tsui, L. (2003). Reproducing social inequalities through higher education: Critical thinking as valued capital. The Journal of Negro Education, 72(3), 318-332. http://www.jstor.com/stable/3211250

Van Zanten, A. (2005). New modes of reproducing social inequality in education: The changing role of parents, teachers, schools and educational policies. European Educational Research Journal, 4(3), 155-169.

Van Zanten, A. (2009). Choisir son école. Stratégies familiales et médiations locales [Choosing a school. Family strategies and local mediations]. Presses Universitaires de France.

Verdier, É. (2010). L'orientation scolaire et professionnelle: Entre assignation et idées floues, l'anarchie organisée (postface) [Educational and vocational guidance: Between assignation and blurred ideas, organized anarchy (afterword)]. Formation emploi, 109(1), 113-126. https://doi.org/10.3917/form.109. 0113

Wang, L. (2011). Social exclusion and inequality in higher education in China: A capability perspective. International Journal of Educational Development, 31, 277-286.

Watts, A. G. (2008). Career guidance and public policy. In J. A. Athanasou \& R. Van Esbroeck (Eds.), International handbook of career guidance (pp. 341-353). Springer. https://doi.org/10.1007/978-14020-6230-8_17

West, A., \& Nikolai, R. (2013). Welfare regimes and education regimes: Equality of opportunity and expenditure in the EU (and US). Journal of Social Policy, 42(3), 469-493.

West, J. (2000). Higher education and employment: Opportunities and limitations in the formation of skills in a mass higher education system. Journal of Vocational Education \& Training, 52(4), 573-588.

Whelan, C. T., Nolan, B., Esping-Andersen, G., Maitre, B., \& Sander, W. (2011). The role of social institutions in intergenerational mobility. In T. M. Smeeding, R. Erikson, \& J. Markus (Eds.), Persitence, power and privilege: The comparative study of intergenerational mobility (pp. 331-367). Russell Sage Foundation.

Willemse, N., \& De Beer, P. (2013). Three worlds of educational welfare states? A comparative study of higher education systems across welfare states. Journal of European Social Policy, 22(2), 105-117.

\section{About the Authors}
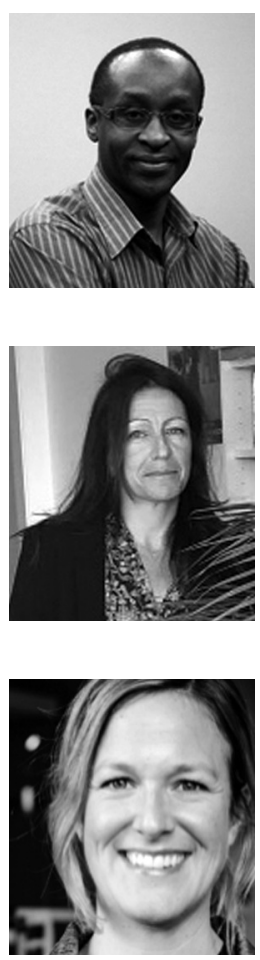

Pierre Canisius Kamanzi is a Sociologist and an Associate Professor at the Faculty of Education, University of Montreal (Province of Quebec, Canada). His research concerns economics and sociology of education. His main research topics are education policy analysis, educational trajectories, social inequalities, and teaching profession. He is currently focused on the differentiation of school pathways and equity.

Gaële Goastellec is a Sociologist. Her main research interests lie in the relationship between education and social organizations, analyzed through the socio-historical comparison of higher education systems and institutions. Professor at the University of Lausanne (Switzerland), she is the current CHER (Consortium of Higher Education Researchers) president, and vice-President of the AISLF research committee on International Comparisons.

Laurence Pelletier is a PhD Candidate in Educational Administration and Foundations at the University of Montreal (Province of Quebec, Canada), and a Vanier Scholar. Her research focuses on higher education access, doctoral education expansion, and PhD students' contribution to academic research production. 